\title{
CONSIDERATIONS ON THE APPLICATION OF THE MAGNETOTELLURIC METHOD WITH NUMERIC MODELING FOR EXPLORATION OF BASINS CONTAINING MAFIC SILLS: THE EXAMPLE OF THE SOLIMÕES UPPER AMAZON BASIN
}

\author{
Marcos Kaíre Miguel Sobrinho ${ }^{1}$ and Lúcia Maria da Costa e Silva²
}

\begin{abstract}
The use of the magnetotelluric method (MT) in Brazil has been predominantly focused on understanding large geological structures. In the 80's the method began to be used in petroleum exploration. Early results have been considered unsatisfactory. We modeled the MT response for the geology of the Solimões Upper Amazon Basin, one of the first basins where the MT method was applied in Brazil, and basalts sills are common, to show its difference in comparison with the seismic section. The synthetic seismic section obtained for the Solimões Basin allows observation of the shallow diabase sill only. However, for MT, the presence of the sill, especially if it is slightly magnetic, increases the depth of investigation possible, or allows the MT method at the very least to investigate the basement better than is possible with the seismic method.
\end{abstract}

Keywords: magnetotelluric, MT, Solimões Basin, diabase sill, modeling, a priori information.

RESUMO. 0 uso do método magnetotelúrico (MT) no Brasil tem sido predominantemente focado na compreensão de grandes estruturas geológicas. Nos anos 80 , o método começou a ser usado na exploração de petróleo. Os primeiros resultados foram considerados insatisfatórios. Modelamos a resposta MT para a geologia da Bacia do Solimões, uma das primeiras bacias onde o método MT foi aplicado no Brasil, e soleiras de diabásio são comuns, para comparação com a seção sísmica modelada para o mesmo local. A seção sísmica sintética obtida para a Bacia do Solimões permite a observação apenas da soleira de diabásio mais rasa. Entretanto, para o MT, a presença da soleira, especialmente se ela é ligeiramente magnética, aumenta a profundidade de investigação possível, ou ao menos permite que o método MT investigue o embasamento melhor do que é possível com a seção sísmica.

Palavras-chave: magnetotelúrico, MT, Bacia do Solimões, soleira de diabásio, modelagem, informação a priori.

\footnotetext{
1 In memoriam.

1,2 Universidade Federal do Pará, Faculdade de Geofísica, Instituto de Geociências / Serviço Geológico do Brasil (CPRM - Geological Survey of Brazil), Av. Dr. Freitas, 3645, Marco, 66095-904 Belém, PA, Brazil - E-mail: lucia.costaesilva@cprm.gov.br
} 


\section{INTRODUCTION}

The magnetotelluric method (MT), and its many variants are based on obtaining, by means of electrical and magnetic field components, the resistivity (and the phase between fields) for depths of about tens of meters to one hundred kilometers (Rokityansky, 1982; Berdichevsky \& Zhdanov, 1984; Vozoff, 1991; Tezkan, 1999; Berdichevsky \& Dmitriev, 2002; Simpson \& Bahr, 2005; Berdichevsky \& Dmitriev, 2008; Chave \& Jones, 2012). Its application is therefore very broad, ranging from the investigation of waste deposit (Tezkan et al., 1996), oil-contaminated areas (Tezkan et al., 2005), underground water (Turberg et al., 1994; Tezkan, 2009), ore minerals (Varentsov et al., 2013), oil (Vozoff, 1972), tectonic provinces (Van Zyl, 1977 and 1978) to the investigation of the asthenosphere (Praus et al., 1990).

The use of the method in Brazil has been predominantly used on understanding large geological structures (works from Instituto Nacional de Pesquisas Espaciais - INPE - and Observatório Nacional - ON). However, the use of MT in Brazil started with oil exploration with the measurements of Hidroservice in the 80's (450 MT-stations in São Paulo State for Paulista Petróleo - PAULIPETRO - from May 1981 to November 1983, and 35 MT-stations in the Solimões Upper Amazon Basin for Petróleo Brasileiro - PETROBRAS - from February to August 1983) (Hidroservice, 2015).

The use of MT for oil\&gas exploration has increased in recent years. Projects related to oil\&gas exploration onshore were carried out in the Paraná Basin (Menezes \& Travassos, 2010; Philipp et al., 2014) and São Francisco Basins (de Lugão et al., 2013), and the National Petroleum Agency of Brazil (ANP) contracted large MT acquisition projects in the Parecis and Paraná Basins (Vital et al., 2014; Taveira et al., 2014). Offshore, a first MT survey was acquired in the Santos Basin (de Lugão et al., 2008; Pinto, 2009). Mineral exploration have also been carried out kimberlite exploration (La Terra, 2011) and others. The method, however, still sees relatively modest use, especially to the investigation of hydrocarbons.

Early MT results focused on oil exploration in Brazil have been considered unsatisfactory, such as those obtained in the Rio Jurua region of the Solimões Basin of the Amazon (Porsani, 1991) and in the Espirito Santo Basin (José, 2005). What are the sources of the possible shortcomings, in the case of MT? Here we explore one possible scenario.

In oil and gas exploration it is common to find magmatic intrusions (diabase sills and basaltic flows), carbonato cover and salt domes. Seismic explorations provide invaluable results for oil exploration, but they have great difficulty imagining below these materials due to their high acoustic impedance (high seismic velocity and high density), which affects the propagation of seismic waves to deeper parts of the basin (Wanderley Filho et al., 2005). In other words, magmatic intrusions, carbonato cover and salt domes reflect and scatter seismic signals, masking the characteristics of the underlying structure. However, these targets have high resistivity.

Electromagnetic methods, among which MT stands out, in contrast, are insensitive to the highly electrically resistive magmatic intrusions, carbonato cover and salt domes. However, it is strongly influenced by the underlying sedimentar basin, which is electrically conductive. Electromagnetic soundings are therefore a valuable compliment to seismic surveys in such areas, providing information which may be interpreted independently or which may be used to constrain parameters in the interpretation of seismic data (Menezes \& Travassos, 2010). Moreover, this type of intrusion is slightly magnetic and this is always overlooked (Li \& Cao, 2005).

In this paper, seismic and MT synthetic results for an area of the oil province of São Mateus in the Solimões Basin (Amazon), a region rich in diabase sills, are used to illustrate the type of responses of the two methods. The MT response taking into consideration the sill magnetism is also investigates, in order to evaluate the convention of neglecting this feature in MT investigations. Delimiting diabase sills is important because they supply heat for organic matter maturation in all Brazilian Paleozoic basins, and also can prevente oil or gas to get to surface (trap).

\section{THE SOLIMÕES BASIN}

The Solimões basin includes the oil and gas producing province Urucú and the gas producing provinces of Juruá and São Mateus in Amazonas State (Brazil) (Fig. 1).

The main generator is the radioactive Devonian shale of the Jandiatuba Formation, whose maximum thickness is 50 meters. Producing reservoirs are Carboniferous sandstone capped by evaporites, which are also Carboniferous. The geological traps are, in general, structural (anticlines associated with reverse faults related to an extensive shear zone) (Eiras, 1988; Eiras et al., 1994).

This basin is important in the Brazilian oil scenario, as it is the only Brazilian Paleozoic basin with commercial hydrocarbon production. The state is the third largest producer of natural gas $(10.8 \%)$ and the seventh producer of oil $(0.4 \%)$ in the country (ANP, 2016).

Wells have been drilled in the basin, but due to the abundance of diabase sills, there are still exploration challenges. Figure 1 shows two different types of structures that are found in the basin. 


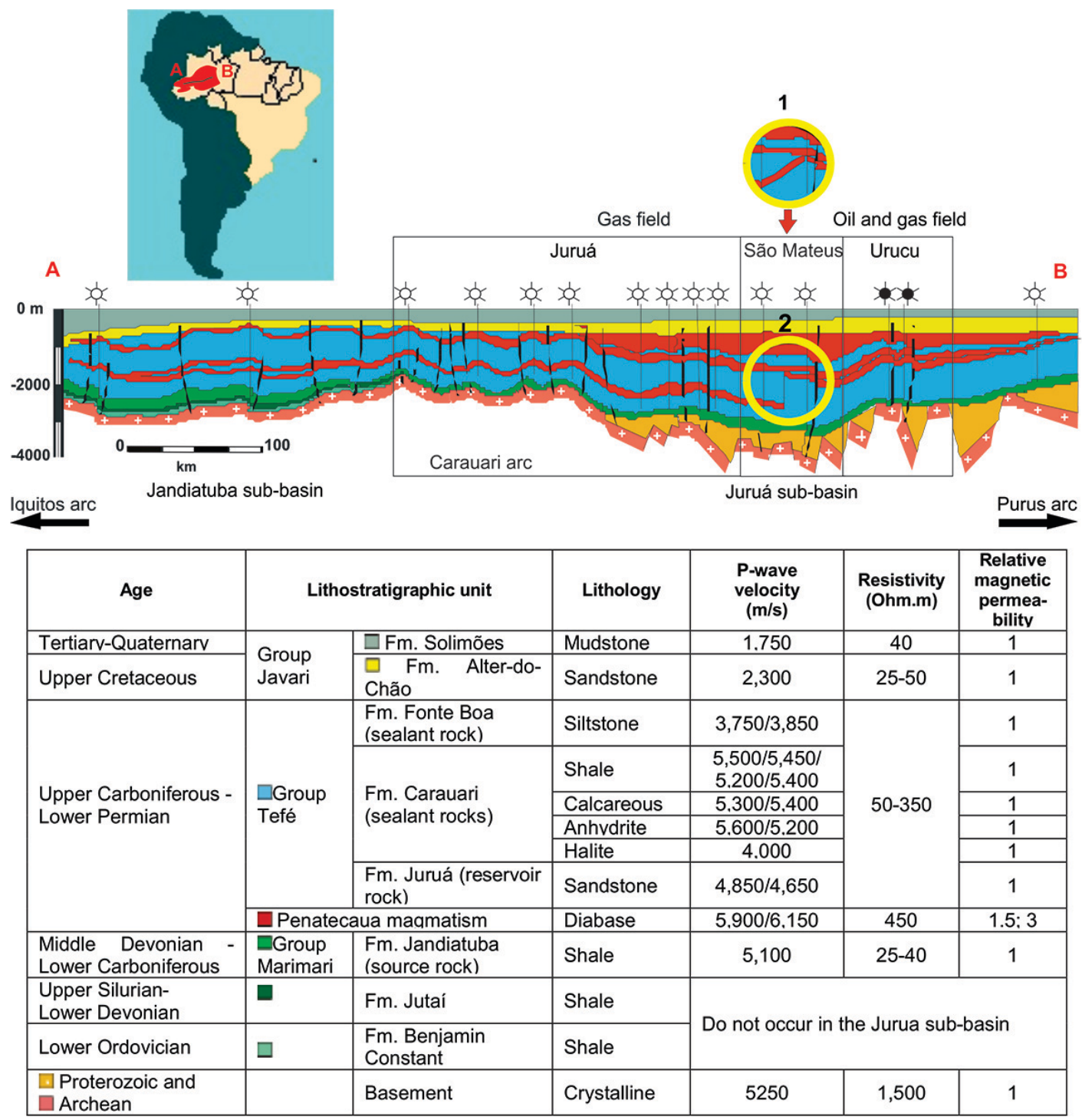

Figure 1 - Location of the Solimões Basin (red) in South America and corresponding geological section (with seismic velocity, resistivity and relative magnetic permeability) highlighting the province of São Mateus: 1) bifurcated model and 2) fault model (modified from Eiras, 1998 and Wanderley Filho et al., 2005).

Structure 1 is a bifurcated structure and structure 2 is a dip-slip fault structure (currently accepted for the São Mateus Province).

\section{SEISMIC MODELING}

The seismic model was constructed with 11 layers of sedimentary rock and 4 bases of diabase, in addition to the top of the basement, a depth of 2,640 m as schown in Figure 2(a). Thicknesses were based on Eiras et al. (1994), as well as velocities (shown on Fig. 1). The model contains both structures 1 and 2. More details on this seismic model are described by Nazaré $(2004,2007)$ and Nazaré et al. (2005).
The modeling was performed by obtaining the solution of the acoustic wave equation using the finite differences program described by (Silva Neto, 2004), for a mesh with 4001 horizontal and 701 vertical points, with each cell measuring $5 \mathrm{~m} \times 5 \mathrm{~m}$.

The synthetic data were generated along a 20,000 m seismic line using a symmetrical split-spread arrangement. The first and last sources were placed at the 3,600 $\mathrm{m}$ and 16,400 m coordinates, respectively. The distance between consecutive sources was $100 \mathrm{~m}$, with 129 sections of common shot configuration being generated. Each experiment used 145 receivers spaced at $50 \mathrm{~m}$, with $2 \mathrm{~s}$ used as total recording time. 


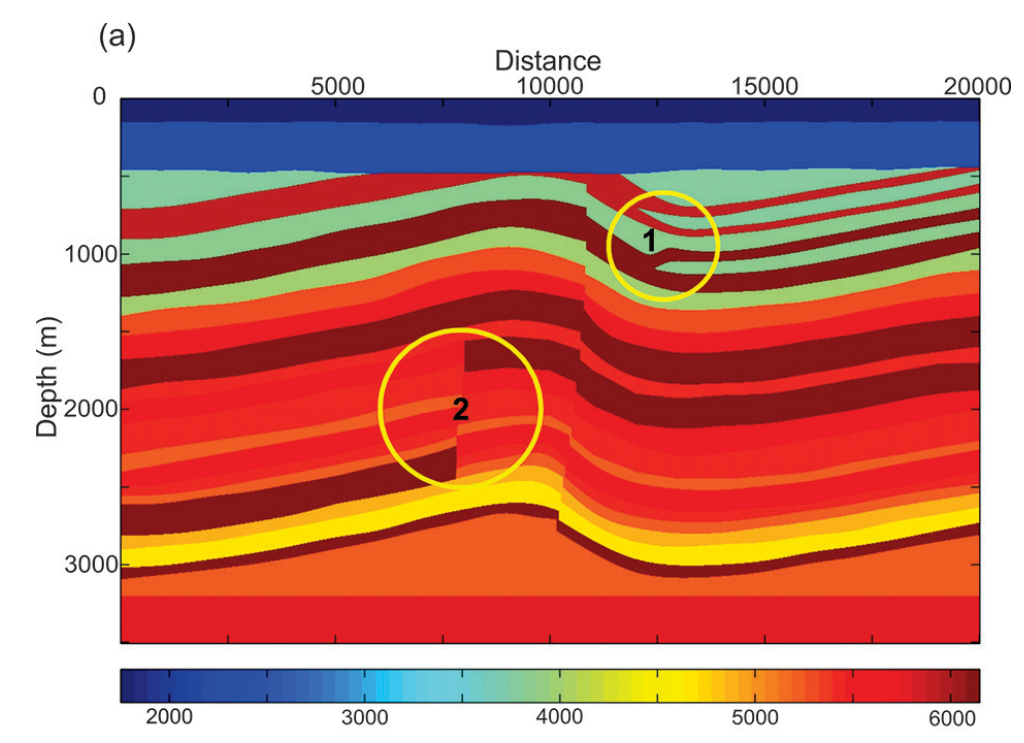

(b)

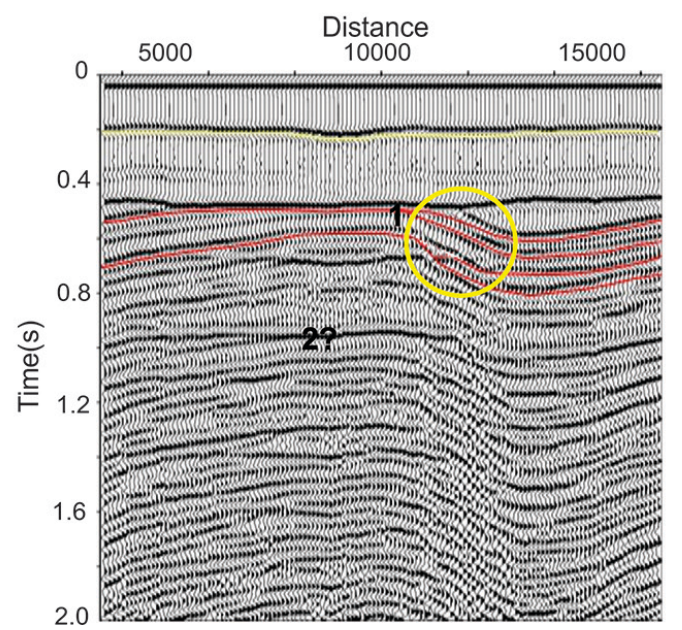

Figure 2 - Seismic modeling. a) Velocity model (m/s) with 1) bifurcated structure and 2) fault structure. b) Raw zero-offset section showing interpretation of the sills (solid red line) (bifurcated model).

Figure 2(b) shows the zero-offset section (Nazaré, 2004; Nazaré et al., 2005). It was processed by the conventional method of common midpoint stacking (CMP). The result obtained does not permit observation below the first sills (bifurcated structures), because of considerable signal loss.

\section{MT MODELING}

The geological section of the province of São Mateus between the STM1 and STM2 wells (Fig. 1) was redesigned with the same horizontal and vertical scales. The section was then discretized, resulting in a mesh with 64 horizontal and 32 vertical cells, with each cell measuring $200 \mathrm{~m} \times 200 \mathrm{~m}$ (12,800 m length and $6,400 \mathrm{~m}$ depth). One section represented the structure 1 (diabase sill bifurcation) and another, the structure 2 (strike-slip dip struc- ture). Both models contain 10 layers, with 5 lithologies with different values of resistivity, as shown in Figure 3.

Thirty stations were positioned at each node of the mesh. To consider the boundary conditions, we increased the lateral and depth limits of the mesh of the model by 5 cells, with increasing dimensions.

An enhanced version of the finite element program developed by Dr. Luiz Rijo was used (Rijo, 1977) to calculate the MT responses of the models for periods of 1 to 0.0002 s of the electromagnetic spectrum.

The experiments were performed with the diabase sill with resistivity equal $400 \mathrm{ohm} . \mathrm{m}$ and relative magnetic permeability equal to 1 (air, also non magnetic), 1.5 and 3 and also with the diabase replaced by evaporite sequence with a resistivity of 350 , 
130 , and 50 ohm.m for comparison with the results obtained with the diabase. It was investigated the bifurcated structure and the fault structure. In total, 27 experiments were carried out (Table 1).

(a)

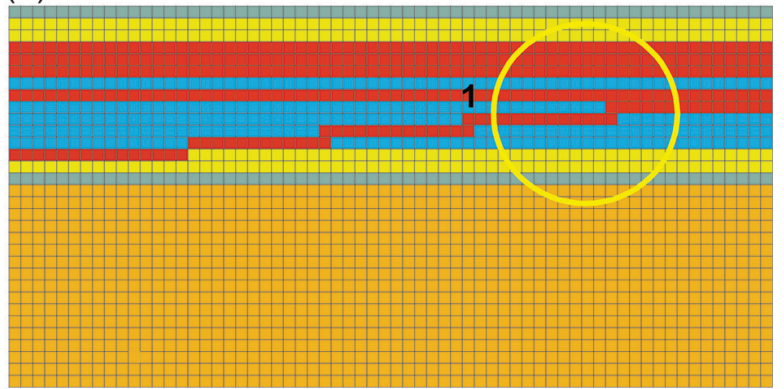

(b)

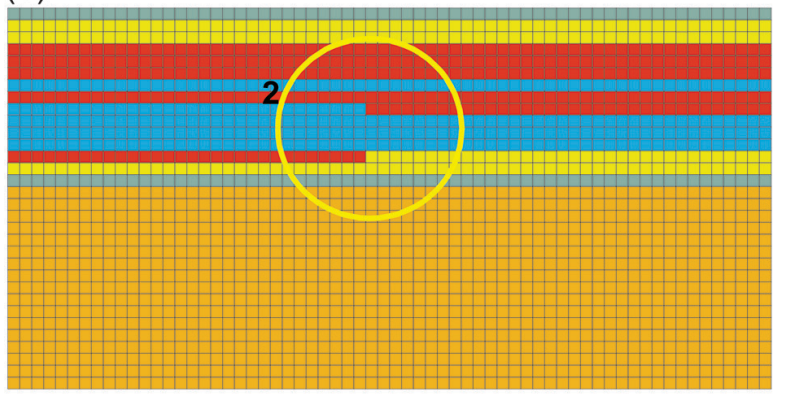

Figure 3 - MT modeling. Resistivity model with: a) bifurcated model (structure 1) and b) strike-slip fault (structure 2).

Figures 4 to 9 show some pseudo-sections. The positions of the MT stations appear in the abscissa and the logarithm of of the period, on the ordinates. The logarithm of the periods increases with the depth, such that the pseudo-section reflects the increase in depth. The isovalues of the logarithm of apparent resistivity $\rho_{a}$ are shown in color and increase from red to blue, while the isovalues of the phase $\theta$, increase from blue to red. Thus, for a conductive body, apparent resistivity and phase move into the red, while for a resistive body, such as the sill and the basement, move into the blue. The pseudo-sections to the left of $\rho_{a}$ and $\theta$ were obtained with the TE mode, while those to the right were acquired using the TM mode. In the TE mode, telluric currents flow in the y direction, perpendicular to the plane shown in Figure 1 (i.e., along the direction of the layers). In the TM mode, telluric currents flow in the direction of the stations' profile, (i.e., perpendicular to the sill).

Figures 4 and 5 show the results for the fault model with the sill replaced by the $50 \mathrm{ohm} . \mathrm{m}$ evaporite sequence and with the

450 ohm.m diabase sill in a 50 ohm.m evaporate sequence, respectively (experiments 23 and 25, Table 1). Figure 6, in turn, shows the responses that would be obtained with the same sill if it were magnetic (relative magnetic permeability equal to 3 ) (experiment 27, Table 1).

In Figure 4, the resistivity in both the TE and TM modes decreases with increase in the period (increase with depth), thus the effect of the resistive basement is not noticeable. In fact, the basement is found at a depth of $3 \mathrm{~km}$ and the skin depth for a section with basement under an evaporite sequence of $50 \mathrm{ohm} . \mathrm{m}$ is about $3.6 \mathrm{~km}$, since the sequence has resistivities of up to 25 ohm.m (sandstone), which further reduces the skin depth. The experiment was, in fact, planned so that the basement is near the end portion of the pseudo-sections of apparent resistivity. The phases in Figure 4 detect the basement, but it is known that the phase enables somewhat deeper investigation than the apparent resistivity.

Comparison of the results of Figure 5, generated without the diabase, with those of Figure 6, obtained with the diabase present, shows that the apparent resistivity grows as the phase decreases for the largest periods (lower portion of pseudo-sections). As the diabase is less conductive than the evaporite, it allows smaller absorption of the electromagnetic wave and therefore larger penetration of the field (larger skin depth).

Consequently, a greater contribution is observed in the response of the basement when there are sills. The package of conductive sediments with the sill will form a single, more compact zone. Thus, with the presence of diabase it becomes easier to detect the basement relief.

In the responses to the magnetic diabase of Figure 6, there is an increase in apparent resistivity of the base section, indicating a greater effect of the basement. In fact, it is expected that permeability attenuates the field, thereby reducing the penetration (reduction of the skin depth). The phase, as Li \& Cao (2005) reported, sustains minor change.

The results show that the presence of a shallow resistive layer, the sill, allows for greater penetration of the EM signal and imaging of the basement.

The responses shown in Figures 7, 8 and 9 for the bifurcated model (experiments 9,10 and 12, Table 1 ) are analogous to those shown respectively in Figures 4, 5 and 6 for the fault model, especially in the case of the magnetic sill. Only the results TE are shown for the bifurcated model because, as shown in the previous pseudo-sections, the response is essentially one dimension (the biggest differences are observed with the sill replaced by $25 \mathrm{ohm}$.m sandstone or shale and the evaporite sequence with 
Table 1 - Main MT experiments.

\begin{tabular}{|c|c|c|c|c|c|}
\hline \multirow[t]{2}{*}{ Experiment } & \multirow[t]{2}{*}{ Structure } & Sill & $\begin{array}{c}\text { Sill } \\
\text { replacement }\end{array}$ & Evaporite & \multirow{2}{*}{$\begin{array}{l}\text { Rel. magnetic } \\
\text { permeability }\end{array}$} \\
\hline & & \multicolumn{3}{|c|}{ (ohm.m) } & \\
\hline 1 & \multirow{12}{*}{ 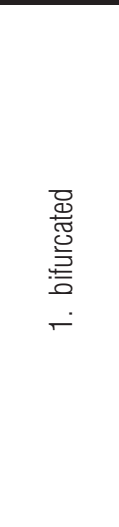 } & & 350 & 350 & 0 \\
\hline 2 & & 450 & & 350 & 0 \\
\hline 3 & & 450 & & 350 & 1.5 \\
\hline 4 & & 450 & & 350 & 3.0 \\
\hline 5 & & & 130 & 130 & 0 \\
\hline 6 & & 450 & & 130 & 0 \\
\hline 7 & & 450 & & 130 & 1.5 \\
\hline 8 & & 450 & & 130 & 3.0 \\
\hline 9 & & & 50 & 50 & 0 \\
\hline 10 & & 450 & & 50 & 0 \\
\hline 11 & & 450 & & 50 & 1.5 \\
\hline 12 & & 450 & & 50 & 3.0 \\
\hline 13 & \multirow{15}{*}{ 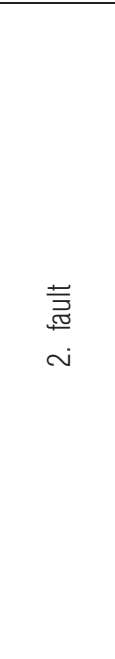 } & & 350 & 350 & 0 \\
\hline 14 & & & 25 & 350 & 0 \\
\hline 15 & & 450 & & 350 & 0 \\
\hline 16 & & 450 & & 350 & 1.5 \\
\hline 18 & & 450 & & 350 & 3.0 \\
\hline 19 & & & 130 & 130 & 0 \\
\hline 19 & & & 25 & 130 & 0 \\
\hline 20 & & 450 & & 130 & 0 \\
\hline 21 & & 450 & & 130 & 1.5 \\
\hline 22 & & 450 & & 130 & 3.0 \\
\hline 23 & & & 50 & 50 & 0 \\
\hline 24 & & & 25 & 50 & 0 \\
\hline 25 & & 450 & & 50 & 0 \\
\hline 26 & & 450 & & 50 & 1.5 \\
\hline 27 & & 450 & & 50 & 3.0 \\
\hline
\end{tabular}

350 and 130 ohm.m resistivity - experiments 14 and 19, Table 1).

Comparison of the results generated for the bifurcated sill with those for the fault model show differences. The sill, although it does not appear separately, can probably not only be detected, but also outlined (although the responses shown are those with the greatest variability), which will be dealt with later.

\section{CONCLUSIONS AND CONSIDERATIONS}

The synthetic P-wave seismic section obtained for the Solimões Basin allows observation of the most shallow diabase sill only. For MT, on the contrary, the presence of the sill, especially if it is slightly magnetic, increases the depth of investigation, or allows the MT at the very least to investigate the basement better than the seismic section (the phase also enables somewhat deeper in- vestigation than the apparent resistivity, detecting the basement). This provides a new interpretation idea to deal with MT data from areas with magnetic units.

The resolution, also the shorter distance from which two distinct features are perceived separately (rather than being seen as only a single feature), of the MT section is inferior to that of the seismic section, because, as ohmic dissipation limits the penetration of high frequency EM waves, the MT method uses low frequency electromagnetic waves, which are governed by the diffusion equation.

As a consequence of the above-mentioned problems, the user-friendliness and usability that are characteristics of the results of the methods, and act as the interface between the interpreter and the geophysical method, are inferior with MT sections, when compared to the seismic method. 

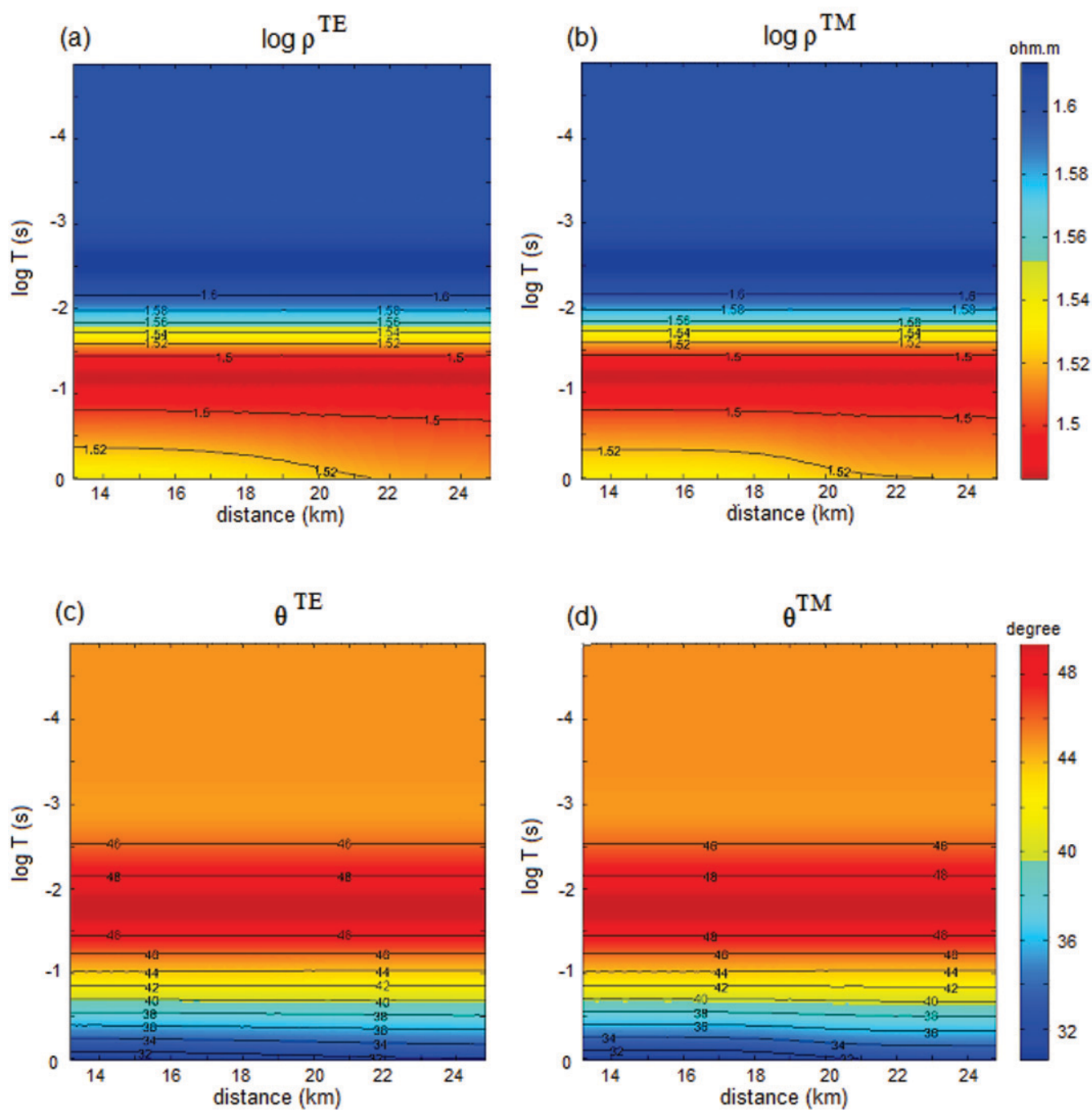

Figure 4 - Fault model with the position of the sill replaced by evaporite sequence of $50 \mathrm{ohm} . \mathrm{m}$. Apparent resistivity mode (a) TE and (b) TM. Phase mode (c) TE and (d) TM.

It is not possible to interpret the pseudo-sections obtained by MT geologically, as is done with the seismic method, without using either forward or inverse interpretation methods. Interpretation enables arriving at probable physical models and these, indeed, being close approximations of the geology of the area, are quite user-friendly and useful. Only with interpretation is it possible to reach individuation of the diabase sill and attempt to individuate between the bifurcated sill and the fault.

With the forward method, the interpreter provides the physical parameters of a pre-established model based on the real geology, and a mathematical formulation allows synthetic measurements to be obtained with them, which the interpreter compares with the field measurements. If synthetic and real measurements are sim- ilar, the model can be considered as one of the many possible models that would fit the observed measurements. If not, new parameters are given and the process repeated until an acceptable adjustment between the measures is found. The result is always linked with the real geology.

The inversion method is a rigorous, mathematical way to find the best model and parameters that fit the real measurements, so it's less painstaking, but its results are somewhat dependent on the a priori information (mathematical relationships) established in one or more stabilizing functionals, which describe the geology (also known as geological functionals) (Silva et al., 2001).

However, describe the geology in terms of mathematical relationships (geological funcionals) is a difficult task of geophysics. 

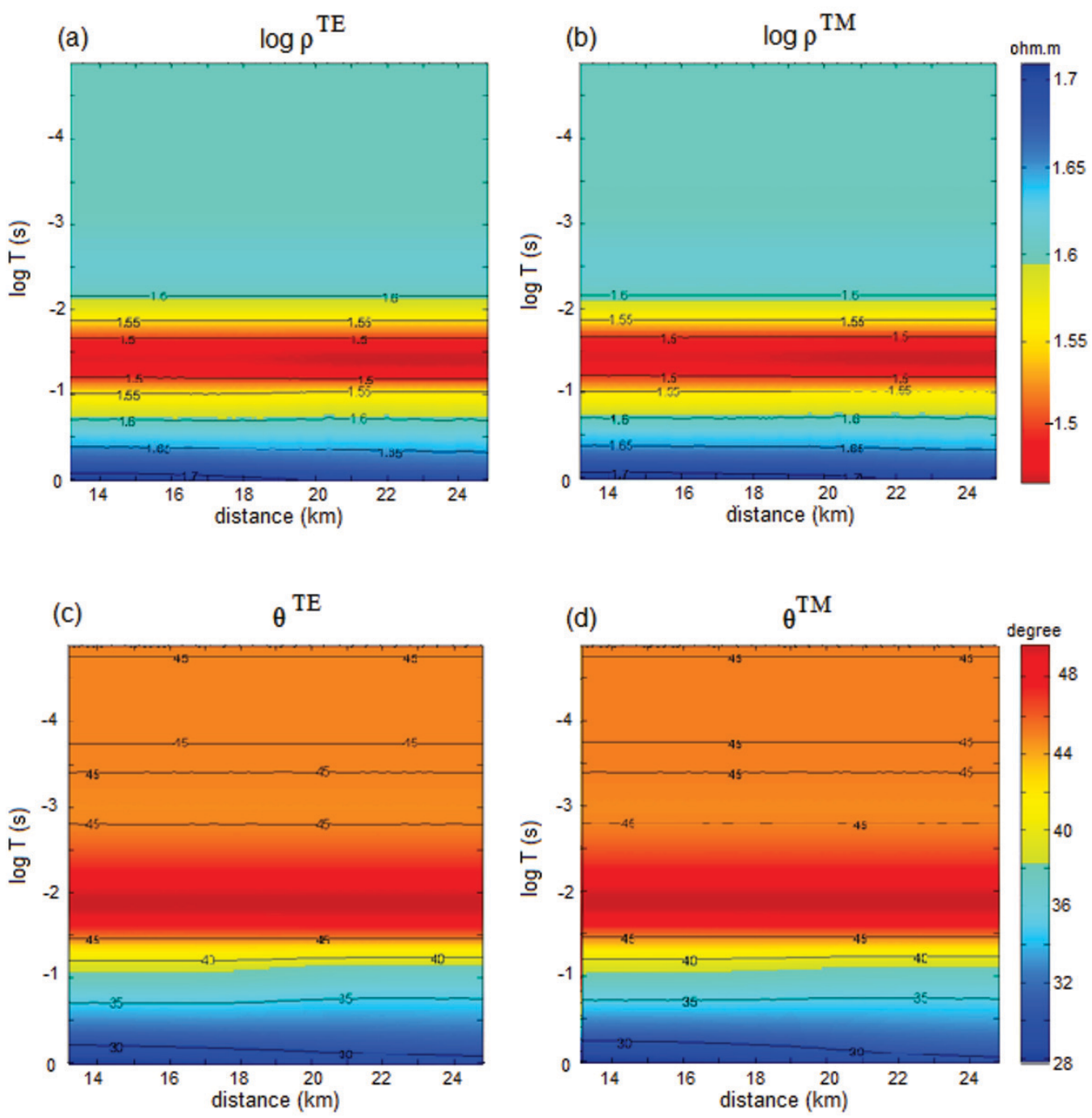

Figure 5 - Fault model with the 450 ohm.m sill. Evaporite sequence: 50 ohm.m. Apparent resistivity model (a) TE and (b) TM. Phase mode (c) TE and (d) TM.

Consequently, almost all of the inversion algorithms reveal some inadequacy with regards to accurately depicting the real environment, often to a very large degree.

In the early stage, due to the inherent lower resolution of MT compared to seismic and the use of 1-D model interpretations, MT was not suitable for imaging structures in geologically complicated areas. Rather MT was just used in imaging the depth to basement in basins.

By other hand, the most used relationship is smoothness, which when translated geologically means that in the subsurface physical properties must be equal among neighboring zones, hence the transition between units, ore bodies, etc. are extremely smooth interfaces. The result is unfocussed geological models, of limited usability. Therefore, the best interpretations use the in- version method and then return to the forward method, where the interpreter at last has the freedom to introduce information that would not be provided by the inversion method only (Jones et al., 2015). It is only very recently that attention has turned to these relationships, i.e. to consider abrupt geological interfaces, for example (Costa \& Silva, 2006).

The main finding of this study is that there are signals of interest in the MT responses generated by the studied models.

\section{ACKNOWLEDGEMENTS}

To Prof. Dr. German Garabito and Priscilla Nazareth for the seismic data and rewarding exchange of ideas. To Professor Dr. Luiz Rijo (in memoriam) for the use of his program and data discussion on magnetic permeability values. 

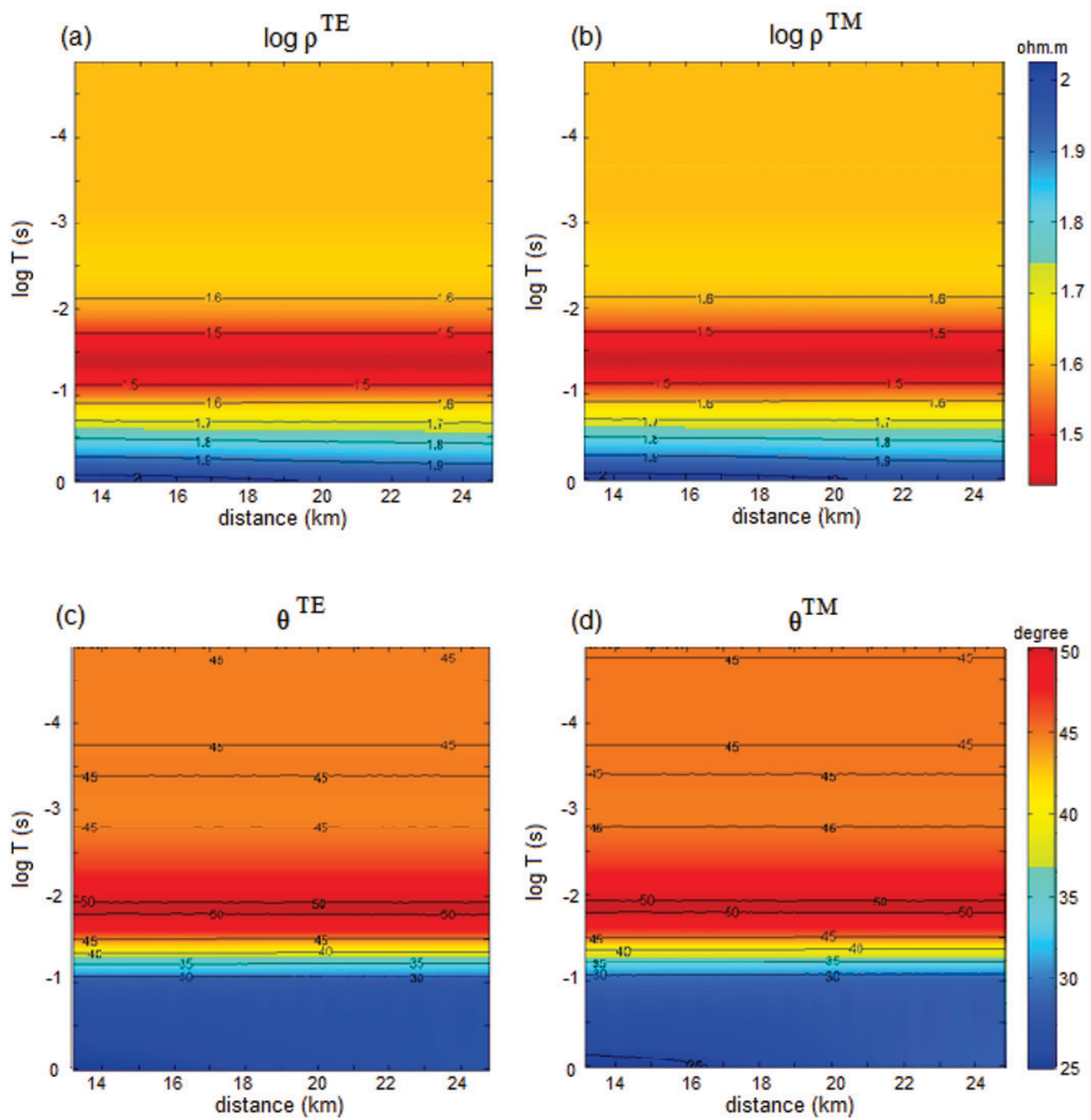

Figure 6 - Fault model with the 450 ohm.m sill, magnetic (relative magnetic permeability = 3). Evaporite sequence: 50 ohm.m. Apparent resistivity mode (a) TE and (b) TM; Phase mode (c) TE and (d) TM.
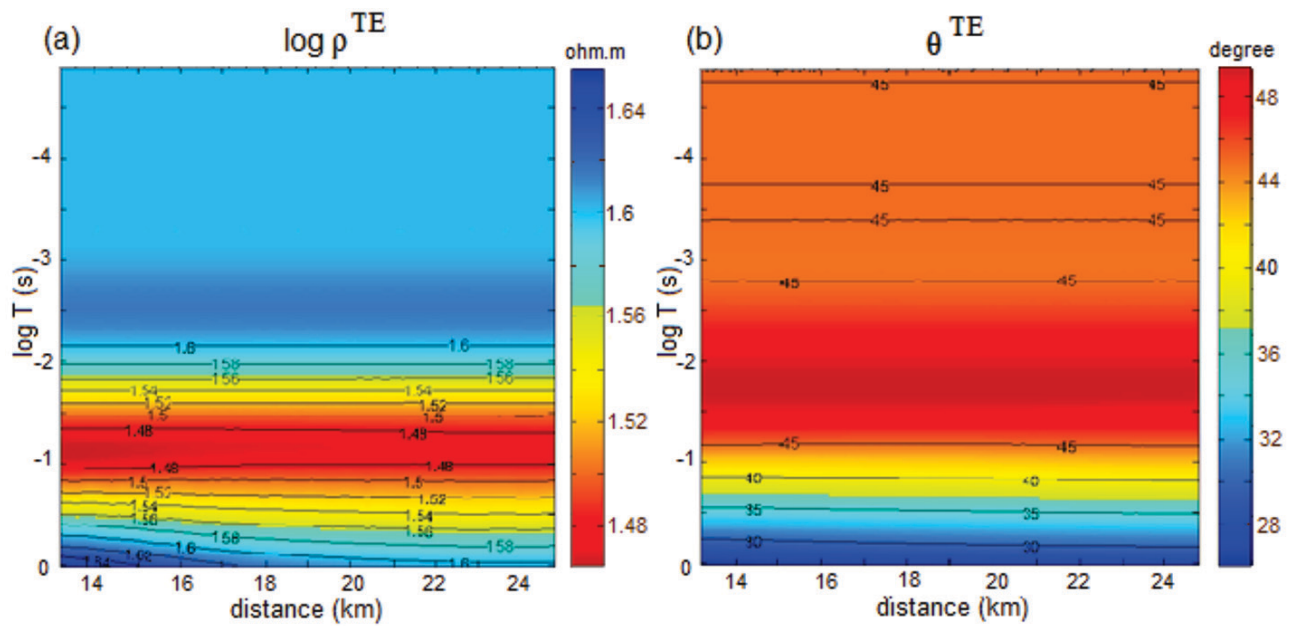

Figure 7 - Bifurcated model with the position of the sill replaced by evaporite sequence of 50 ohm.m. (a) Apparent resistivity and (b) Phase mode TE. 

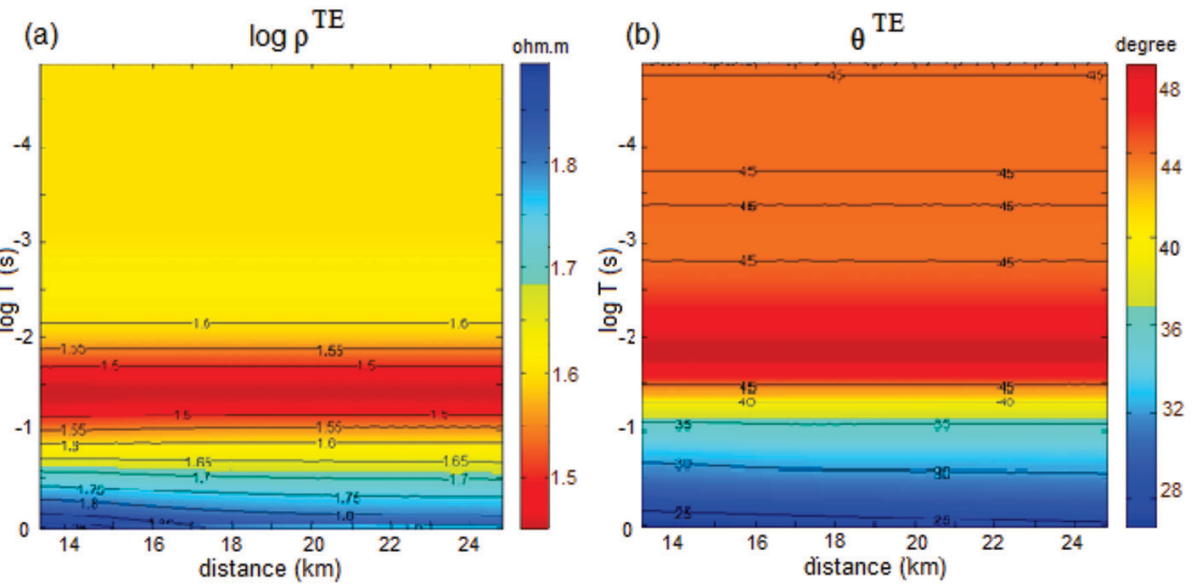

Figure 8 - Bifurcated model with the 450 ohm.m sill. Evaporite sequence: 50 ohm.m. (a) Apparent resistivity and (b) Phase mode TE.
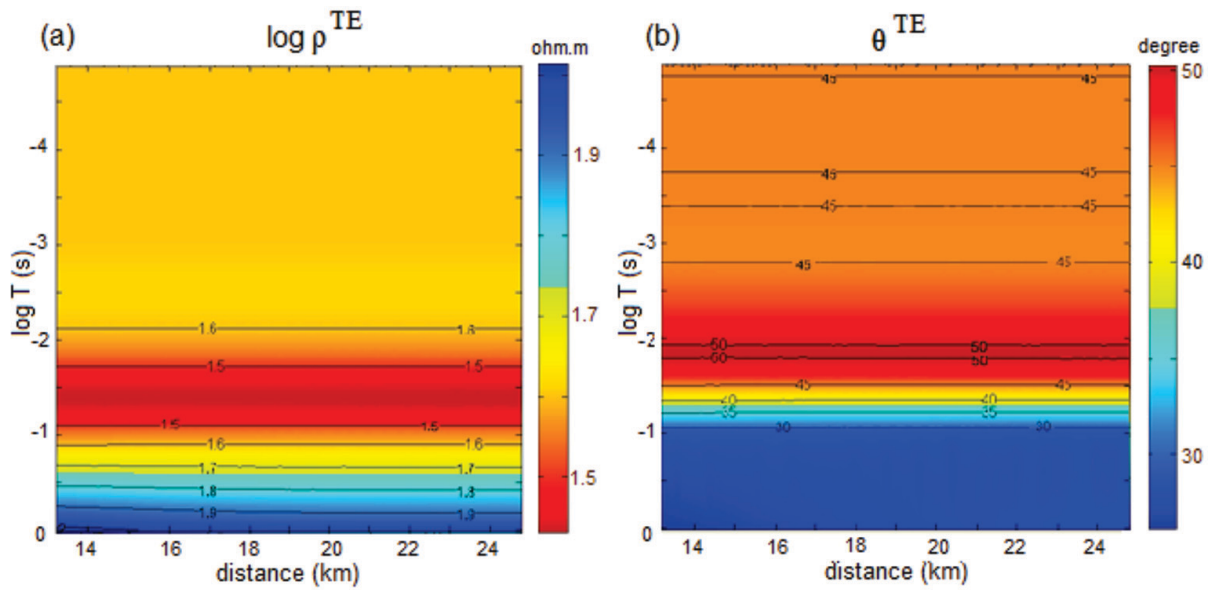

Figure 9 - Bifurcated model with the $450 \mathrm{ohm} . \mathrm{m}$ sill, magnetic (relative magnetic permeability $=3$ ). Evaporite sequence: 50 ohm.m. (a) Apparent resistivity and (b) Phase mode TE.

\section{REFERENCES}

ANP. 2016. Anuário Estatístico Brasileiro do Petróleo, Gás Natural e Biocombustíveis. ANP. Rio de Janeiro, Brazil. 264 pp.

BERDICHEVSKY MN \& DMITRIEV VI. 2002. Magnetotellurics in the context of the theory of ill-posed problems. SEG, Tulsa. v. 11. 215 pp. (Investigations in Geophysics).

BERDICHEVSKY MN \& DMITRIEV VI. 2008. Models and Methos of Magnetotellurics. Springer, Berlin. 382 pp.

BERDICHEVSKY MN \& ZHDANOV MS. 1984. Advanced theory of deep geomagnetic sounding. Elsevier, Amsterdam. 408 pp.

COSTA E SILVA LM. 2006. DesG: Uma nova metodologia para inversão e coleta de dados magnetotelúricos. Doctor Thesis on Geophysics - Universidade Federal do Pará, Brazil. 183 pp.
CHAVE AD \& JONES AG. 2012. The Magnetotelluric Method. Theory and Practice. Cambridge University Press, Cambridge. 570 pp.

DE LUGÃO P, FONTES SL, LA TERRA EF, ZERILLI A, LABRUZZO T \& BUONORA P. 2008. First Application of Marine Magnetotellurics Improves Depth Imaging in the Santos Basin, Brazil. In: 70th EAGE Conference \& Exhibition, Rome, paper P192.

DE LUGÃO P, SENDEROWITZ S, MENEZES A, NUNES D, GUARAGNA I, PASTANAA \& BRAGA B. 2013. A Multiclient Magnetotelluric Survey on the Proterozoic São Francisco Basin to Aid the Exploration for Oil \& Gas. In: 75th EAGE Conference \& Exhibition incorporating SPE EUROPEC, London, paper Th-P07-06.

EIRAS JF. 1998. Tectônica, sedimentação e sistemas petrolíferos da Bacia do Solimões, Estado do Amazonas. In: TAHA M (Ed.). Searching for Oil and Gas in the Land of Giants. The Search Magazine, Edição Especial sobre o Brasil. Argentina: Schlumberger. 
EIRAS JF, BECKER CR, SOUZA EM, GONZAGA FG, DA SILVA JGF, DANIEL LMF, MATSUDA NS \& FEIJÓ FJ. 1994. Bacia do Solimões. Boletim de Geociências da Petrobras, 8(1): 17-45.

HIDROSERVICE. 2015. Trabalhos Hidroservice - Consulta por País. Available on: <http://www.hidroservice.com.br/trabalho/index.htm>. Acess on: September 30, 2015.

JONES AG, LEDO J \& FERGUSON IJ. 2005. Electromagnetic images of the Trans-Hudson orogen: the North American Central Plains anomaly revealed. Canadian Journal of Earth Sciences, 42: 457-478.

JOSÉ SA. 2005. Modelagens magnetotelúrica e sísmica na bacia do Espirito Santo. Master Dissertation on Geophysics - Universidade Estadual do Norte Fluminense, Rio de Janeiro, Brazil. 149 pp.

LA TERRA EF. 2011. Interpretação 3D integrada do pipe kimberlítico Régis (MG). Doctor Thesis on Geophysics - Observatório Nacional, Rio de Janeiro, Brazil. 80 pp.

LIX \& CAO J. 2005. A study of the influence of magnetic susceptibility on MT response. Chinese Journal of Geophysics, 48(4): 947-950.

MENEZES PTL \& TRAVASSOS JM. 2010. Magnetotellurics as a modeling tool in the extensive magmatic context of Paraná Basin, Brazil. The Leading Edge, 29(7): 832-840.

NAZARÉ CPP. 2004. Modelagem sísmica em um modelo geológico baseado em dados da Bacia do Solimões. Undergraduate Final Project, Geophysics, Centro de Geociências, Universidade Federal do Pará, Brazil. 21 pp.

NAZARÉ CPP. 2007. Processamento Sísmico CMP e CRS de dados sintéticos acústicos e elásticos representativos das Bacias Paleozóicas da Região Amazônica. Master Dissertation on Geophysics, Centro de Geociências, Universidade Federal do Pará, Brazil. 100 pp.

NAZARÉ CPP, CALLAPINO GG, EIRAS JF \& PASCHOAL JR WG. 2005. Aplicação dos métodos PMC e SRC em dados sísmicos sintéticos de um modelo representativo da Bacia do Solimões, Região Amazônica, Brasil. In: International Congress of the Brazilian Geophysical Society, 9., 2005, Salvador. Expanded Abstracts... Salvador, Brazil: SBGf, 2005. 14861490.

PHILIPP RP, ROLIM SBA, MALTA L, JELINEK AR, VIANA A, LAVINAE, CAGLIARI J \& FACCINI UF. 2014. Estruturação do Arco de Rio Grande e da Sinclinal de Torres, Bacia do Paraná, RS: Evidências por levantamentos magnetotelúricos. In: Simpósio Brasileiro de Geofísica, 6., 2014, Porto Alegre. Resumos Expandidos... Porto Alegre, Brazil: SBGf, 2014. CD-ROM.

PINTO VR. 2009. 0 Método Magnetotelúrico Marinho (MMT) na Exploração de Hidrocarbonetos. Master Dissertation on Geophysics - Observatório Nacional, Rio de Janeiro, Brazil. 87 pp.

PORSANI JL. 1991. Estudo da estrutura geo-elétrica da região do Juruá, AM, pelo método magnetotelúrico. Master Dissertation on Geophysics, Centro de Geociências, Universidade Federal do Pará, Brazil. 105 pp.
PRAUS 0, PĚČVÁ J, PETR V, BABUŠKA V \& PLOMEROVÁ J. 1990. Magnetotelluric and seismological determination of the lithosphereasthenosphere transition in Central Europe. Physics of the Earth and Planetary Interiors, 60: 212-228.

RIJO L. 1977. Modeling of electric and electromagnetic data. PhD Thesis on Geophysics - Department of Geology and Geophysics, University of Utah. $242 \mathrm{pp}$.

ROKITYANSKY II. 1982. Geoelectromagnetic Investigation of the Earth's Crust and Mantle. Springer, Berlin. 381 pp.

SILVA NETO FA. 2004. Modelagem acústica por diferenças finitas e elementos finitos em 2-D e 2,5-D. Master Dissertation on Geophysics, Centro de Geociências, Universidade Federal do Pará, Brazil. 103 pp.

SILVA JBC, MEDEIROS WE \& BARBOSA VCF. 2001. Pitfalls in Nonlinear Inversion. Pure and Applied Geophysics, 158: 945-964.

SIMPSON F \& BAHR K. 2005. Practical Magnetotellurics. Cambridge University Press, Cambridge. 270 pp.

TAVEIRA D, FONTES SL, LA TERRA EF \& MIQUELUTTI LG. 2014. Imageamento Magnetotelúrico da Porção Central da Bacia do Paraná. In: Simpósio Brasileiro de Geofísica, 6., 2014, Porto Alegre. Resumos Expandidos... Porto Alegre, Brazil: SBGf, 2014. CD-ROM.

VITAL LB, LA TERRA EF, FONTES SL \& MIGUELUTTI LG. 2014. Interpretação Geológica/Geofísica da Parte Central da Bacia dos Parecis, a partir de Dados Magnetotelúricos. In: Simpósio Brasileiro de Geofísica, 6., 2014, Porto Alegre. Resumos Expandidos... Porto Alegre, Brazil: SBGF, 2014. CD-ROM.

TEZKAN B. 1999. A review of environmental applications of quasistationary electromagnetic techniques. Surveys in Geophysics, 20: 279-308.

TEZKAN B. 2009. Radiomagnetotellurics. In: KIRSCH R (Ed.). Groundwater Geophysics: A Tool for Hydrogeology. 2 ed., Springer Verlag, Berlin Heidelberg. Ch. 10: 295-316.

TEZKAN B, GOLDMAN M, GREINWALD S, HÖRDT A, MÜLLER I, NEUBAUER FM \& ZACHER G. 1996. A joint application of radiomagnetotellurics and transient electromagnetics to the investigation of a waste deposit in Cologne (Germany). Applied Geophysics, 34(3): 199-212.

TEZKAN B, GEORGESCU P \& FAUZI U. 2005. A radiomagnetotelluric survey on an oil-contaminated area near the Brazi Refinery, Romania. Geophysical Prospecting, 53(3): 311-323.

TURBERG P, MUELLERI \& FLURY F. 1994. Hydrogeological investigation of porous environments by radio magnetotelluric-resistivity (RMT-R 12-240 kHz). Journal of Applied Geophysics, 31: 133-143.

VAN ZYL JSV. 1977. Resistivity and the continental crust in Southern Africa. Nature, 265: 614-615. 
VAN ZYL JSV. 1978. The relationship between the deep electrical resistivity structure and tectonic provinces in southern Africa. Transactions of the Geological Society of South Africa, 81: 129-142.

VARENTSOV IVM, KULIKOV VA, YAKOVLEV AG \& YAKOVLEV DV. 2013. Possibilities of Magnetelluric Methods in Geophysical Exploration for Ore Minerals. Physics of the Solid Earth, 49(3): 309-328.

VOZOFF K. 1972. The Magnetotelluric Method in the exploration of sedimentar basins. Geophysics, 37(1): 98-141.

VOZOFF K. 1991. The magnetotelluric method. In: NABIGHIAN MN (Ed.). Electromagnetic Methods in Applied Geophysics. Society of Exploration Geophysicists, 2B: 641-711.

WANDERLEY FILHO JR, TRAVASSOS WAS \& ALVES DB. 2005/2006. 0 diabásio nas bacias paleozóicas amazônicas - Herói ou Vilão? Boletim de Geociências da Petrobras, 14(1): 177-184.

Recebido em 6 março, 2017 / Aceito em 26 abril, 2017

Received on March 6, 2017 / Accepted on April 26, 2017 